\title{
THE USE OF HERBAL DIETARY SUPPLEMENTS IN DIABETIC PATIENTS: ROLE OF HEALTHCARE PROFESSIONALS
}

\author{
Ivana Damnjanović1 ${ }^{1}$ Dušanka Kitić1 , Nikola Stefanović ${ }^{1}$, \\ Snežana Zlatković-Guberinić2, Aleksandra Catić-Đorđević ${ }^{1}$, \\ Radmila Veličković-Radovanović1,3
}

\begin{abstract}
Nowadays, the use of herbal dietary supplements in diabetic patients is becoming very popular, following the opinion that the use of dietary supplements combined with conventional anti-diabetic drugs is absolutely safe and justified. The aim of this study was to investigate the potential role of healthcare professionals regarding the use of herbal dietary supplements with hypoglycemic effect in the population of patients with diabetes mellitus type 2 .

The research in the form of an analytical cross-sectional study was conducted in 6 pharmacies in the territory of Nis during October 2013. The study enrollment criterion was to include the patients diagnosed with type 2 diabetes who used pharmacotherapy in addition to herbal supplements.

The surveyed women showed a statistically significant difference in the frequency of using herbal supplements compared to the group of men $(P<0.001)$. There was a statistically significant difference between the age groups of respondents in relation to the influence of health service professionals and media on making decisions about the use of herbal dietary supplements.

A multidisciplinary approach of healthcare professionals to pharmacotherapy of chronic disease is recommended. It is essential that doctors and pharmacists recognize the safety and efficacy issues prior to recommending herbal dietary supplements for diabetes care, because of the limited data available regarding the use of dietary supplements in diabetes.
\end{abstract}

Acta Medica Medianae 2017;56(4):25-30.

Key words: herbal dietary supplements, diabetic patients, healthcare professionals

${ }^{1}$ General Practice Hospital, Aleksinac, Serbia

${ }^{2}$ Clinic for Orthopedic Surgery, Clinical Center Niš Niš, Serbia

${ }^{3}$ University of Niš, Faculty of Medicine, Niš, Serbia

Contact: Ivana Damnjanović

Faculty of Medicine, Department of Pharmacy

Bulevar dr Zorana Đinđica 81,

18000 Nis, Serbia

e-mail: ivanad.ph@gmail.com

\section{Introduction}

Diabetes mellitus (DM) is an epidemic disease, and its prevalence is growing at an alarming rate in both developed and developing countries (1). The prevalence of type 2 DM worldwide has an increasing trend and it was estimated that 200 million people had type 2 diabetes in 2010, and the number is expected to reach 300 million by the year 2025 (2).

The management of DM type 2 is complex and requires continuing medical care and per- sistent patient self - management education in order to prevent acute complications and to reduce the risk of long-term complications (3). Today, herbal dietary supplements in diabetic patients are becoming very popular, following the opinion that the use of dietary supplements combined with conventional anti-diabetic drugs is absolutely safe and justified (4).

The aim of this study was to investigate the potential role of healthcare professionals (physicians, pharmacists) regarding the use of herbal dietary supplements with hypoglycemic effect in the population of patients with type $2 \mathrm{DM}$.

\section{Material and methods}

The research in the form of an analytical cross-sectional study was conducted in 6 "Remedia" Pharmacy Health Facilities in the territory of Nis during October 2013. The criterion set for the study was to enroll the patients diagnosed with type 2 diabetes who used herbal dietary supplements in addition to pharmacotherapy.

The method of study was a survey of the total of 519 respondents. The survey was divided 
into two parts. In the first part, the questions were related to the patient personal data (age, body mass index, disease duration and pharmacological groups of drugs patients used in the treatment of type 2 DM). The second part of the survey was related to the frequency of use of herbal dietary supplements and the impact of advice of health care professionals (doctors, pharmacists) and the media (television, radio, internet) on the choice of dietary supplements. Herbal dietary supplements were based on the extracts of: Gingseng radix Panax ginseng (Ginseng), Allii sativi bulbus Allium sativum L. (Garlic), Aloe vera leaf - Aloe Barbadensis (Aloe), Cinnamomi cortex - Cinnamomum ceylanicum (Cinammon), Hyperici herbaHypericum perforatum (St. John's wort), Aronia fructus - Aronia Melanocarpa (Siberian Aronia) and Myrtilli fructus - Vaccinium myrtillus L. (Blueberry).

The data collected were statistically analyzed and processed by using descriptive statistics as well as the appropriate tests of statistical significance ( $x^{2}$-test of independence with the correction of continuity according to Yeats), illustrated with tables and graphs. The database was created in the Excel statistical program, and for statistical processing the SPSS program was applied - version 19.0 (Statistical Package for So-cial Sciences). All statistical tests would be accepted if the null hypothesis was equal to or less than $5 \%$.

\section{Results}

The research conducted included 276 women and 243 men divided into four age categories. Demographic characteristics of the surveyed patients (age, body mass index, disease duration and pharmacological groups of drugs patients used in the treatment of DM type 2) are shown in Table 1.

Table 1. Demographic characteristics of the surveyed patients

\begin{tabular}{|c|c|c|c|c||}
\hline \multirow{2}{*}{ Age (years) } & \multicolumn{2}{|c|}{ Female } & \multicolumn{2}{c|}{ Male } \\
\cline { 2 - 5 } & Number & $\%$ & Number & $\%$ \\
\hline \hline $1(<45)$ & 49 & 9.44 & 33 & 6.36 \\
\hline $2(45-54)$ & 87 & 16.76 & 63 & 12.14 \\
\hline $3(55-54)$ & 63 & 12.14 & 60 & 11.56 \\
\hline $4(<64)$ & 77 & 14.84 & 87 & 16.76 \\
\hline Duration of disease (years) & \multicolumn{5}{|c|}{} \\
\hline$\leq 5$ & 41 & 7.90 & 44 & 8.48 \\
\hline $6-9$ & 161 & 31.02 & 112 & 21.58 \\
\hline$\geq 10$ & 74 & 14.26 & 87 & 16.76 \\
\hline Type of antidiabetic therapy & \multicolumn{5}{|c|}{} \\
\hline Oral antidiabetics & 179 & 34.49 & 151 & 29.09 \\
\hline Insulin + oral antidiabetics & 97 & 18.69 & 92 & 17.73 \\
\hline \multirow{2}{*}{ BMI (kg/m $\left.{ }^{2}\right)$} & $\mathrm{X}$ & SD & $\mathrm{X}$ & SD \\
\cline { 2 - 5 } & 28.58 & 3.63 & 25.27 & 2.78 \\
\hline
\end{tabular}

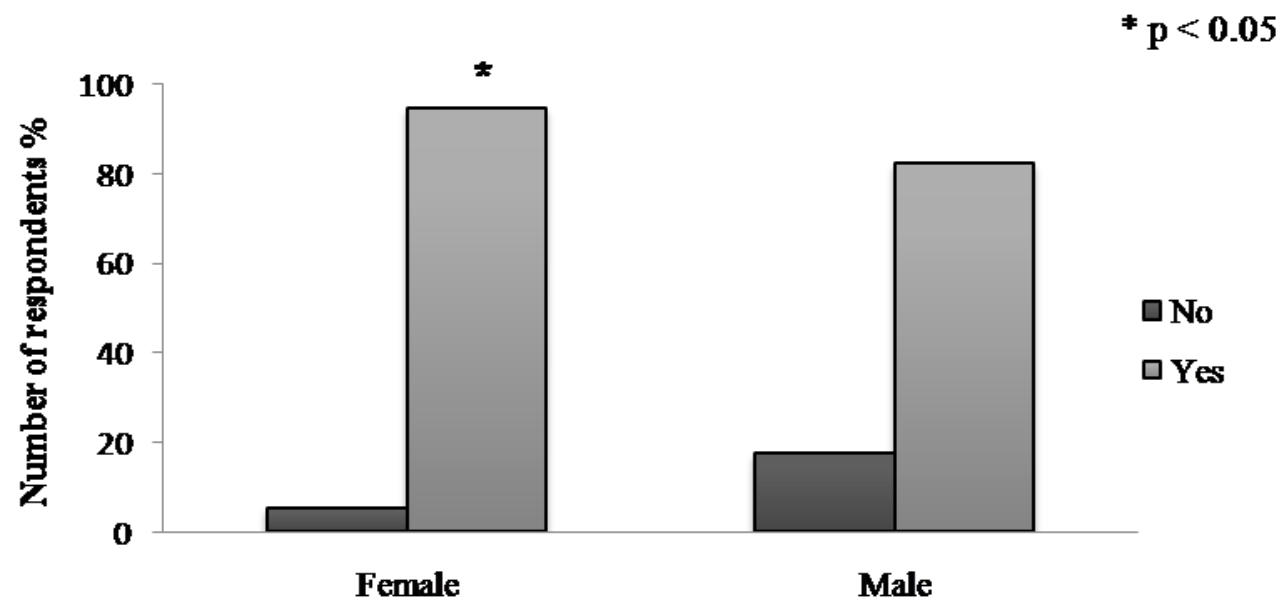

Figure 1. The frequency of use of herbal dietary supplements in relation to gender 
More than half of diabetic respondents (52.60\%) had been diagnosed with DM 6-9 years before, while $16.38 \%$ and $31.02 \%$ of the respondents had suffered from DM for less than 5 years and for more than 10 years approximately; 63.58 $\%$ of respondents used only oral hypoglycemic agents in the treatment of type 2 DM, while 36.42 $\%$ of the respondents used a combined therapy with oral hypoglycemics and insulin. In the present study, the body mass index (BMI) of diabetic female respondents $(28.58 \pm 3.63)$ was found to be higher than that of surveyed male respondents (25.27士2.78).

The frequency of use of herbal dietary sup- plements with hypoglycemic effect by diabetic respondents by the factor of gender is shown in Figure 1.

As shown in Figure 1, 94.57\% of women and $82.30 \%$ of men used dietary supplements with hypoglycemic effect along with the prescribed therapy in the treatment of type 2 DM. Female respondents (50.29\%) showed a higher frequency of use of dietary supplements compared to males.

The influence of healthcare professionals (physicians, pharmacists) and media information on the use of herbal dietary supplements in relation to gender is shown in Figure 2.

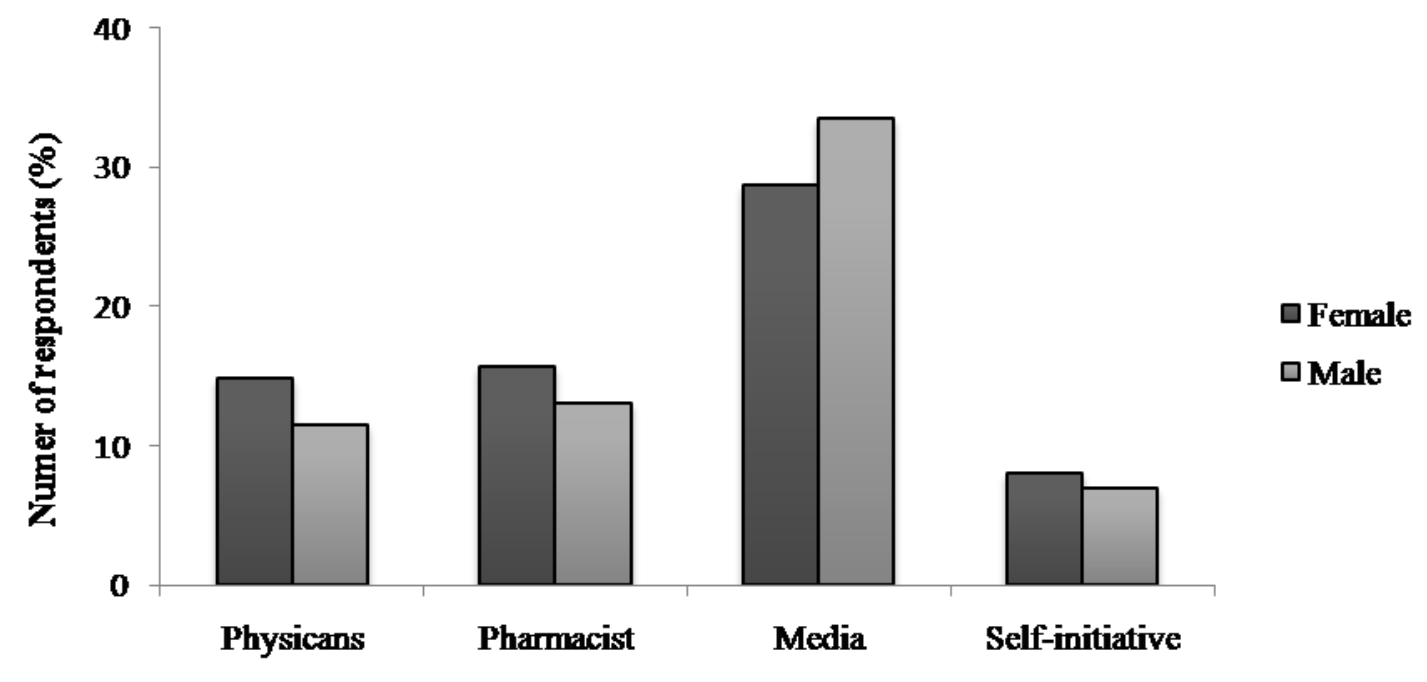

Figure 2. The influence of healthcare professionals and media information on the use of herbal dietary supplements in relation to gender

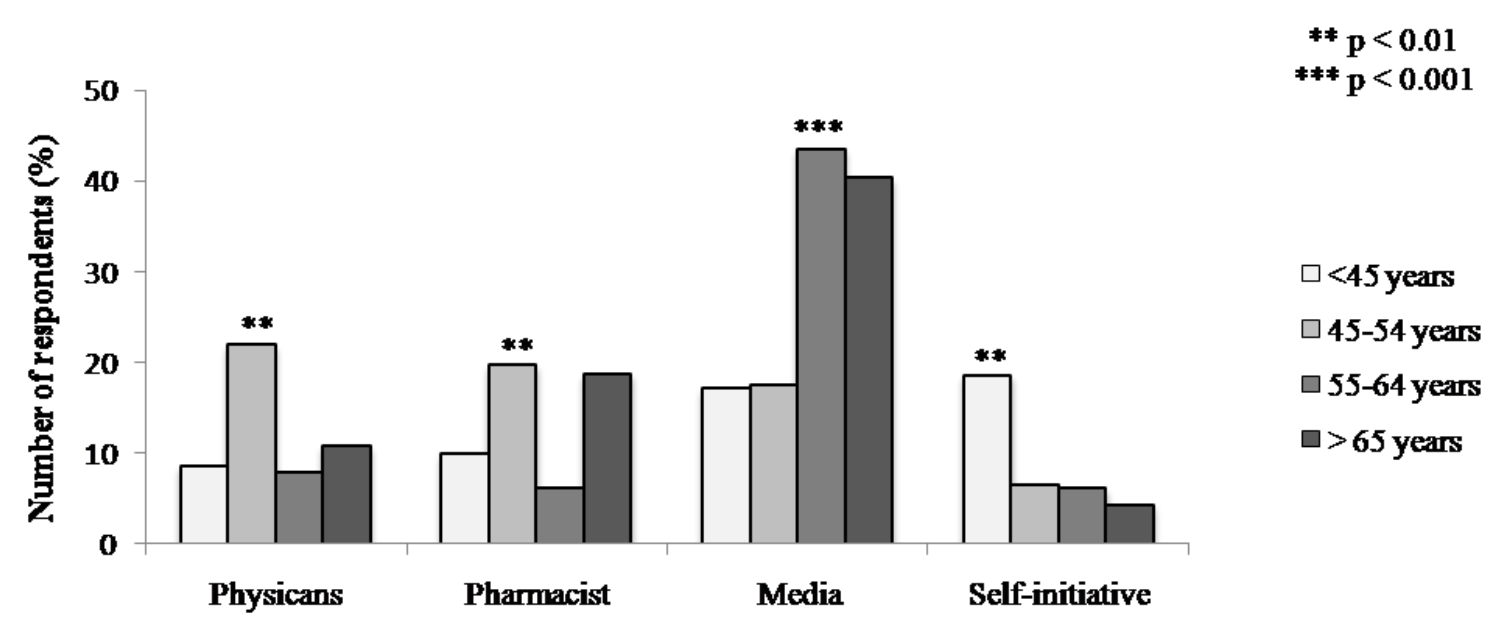

Figure 3. The influence of healthcare professionals and media information on the use of herbal dietary supplements in relation to patient age 
There was no significant statistical difference in relation to gender of the respondents who used herbal dietary supplements along with the prescribed therapy in the treatment of type 2 DM.

The influence healthcare professionals (physicians, pharmacists) and media information concerning their counselling about the use of dietary supplements related to gender categories of the respondents is shown in Figure 3.

As shown in Figure 3, there was a statistically significant difference between the age groups of respondents in relation to the influence of health service professionals and media on making decisions about the use of herbal dietary supplements. Respondents aged 45-54 followed the recommendation and advice of their doctors or pharmacists, while the population of respondents over the age of 55 was mostly influenced by media (TV, radio, internet) in making decisions about the use of herbal dietary supplements with hypoglycemic effect in type 2 DM.

\section{Discussion}

The use of dietary supplements and herbal medicine for general health and the prevention and treatment of chronic diseases has been on the rise in recent years $(5,6)$. The use of dietary supplements is common in the population of diabetics and their purpose is to alleviate the symptoms of this disease $(7,8)$. The results of conducted studies have shown a statistically significant difference in the frequency of use of herbal dietary supplements in the group of surveyed diabetic women compared to the group of diabetic men (Figure 1). Similar results were found in the study conducted in the community of Portuguese pharmacies (5), in India (9) and in Ethiopia (10), while the frequency of use of herbal and dietary preparations was significantly lower in diabetic patients in America (14\%) (11).

Before recommending herbal dietary supplementation for patients with diabetes, the type and severity of the disease should be considered, as well as other agents used for glycemic control. Patients should also be closely monitored for adverse events (12). Optimal doses of natural products are often unclear, many products are not standardized, and a huge variability can be seen from one to another manufacturer, or from one batch to another. Pharmacists must be able to determine which brands of herbal and dietary supplements can be reliably recommended to consumers and use manufacturer labeling as a dosing guide (13).

In the conducted studies, there was no significant statistical difference in relation to gender of the respondents who used herbal dietary supplements along with the prescribed therapy in the treatment of type 2 DM (Figure 2), but there was a statistically significant difference between the age groups of respondents concerning the choice of herbal dietary supplements with hypoglycemic effect. It should be mentioned that the respondents aged 45-54 followed the recom- mendation and advice of their healthcare providers (doctors or pharmacists), while the population of respondents over the age of 55 were mostly influenced by mass media in making their decisions about the use of herbal dietary supplements with hypoglycemic effect (Figure 3.).

Further, alternative medicine approaches and polypharmacy among the elderly and patients with chronic diseases are very common (14). Many studies have found that various medications are associated with negative health outcomes, but more research is needed to further delineate the consequences associated with unnecessary drug use in the elderly. In Germany, nearly half of the patients with diabetes use different types of dietary supplements on their own (15), but in India more than $50 \%$ of patients opted for herbal and dietary medications only after the advice by their pharmacists (9). Mass media, such as television, newspapers, internet and radio, can be a powerful tool in public health education (16). On the other hand, the advertising of dietary supplements and their false presentation as highly effective can be a confusing fact leading to possible side effects and adverse drug interactions (17). In that case, healthcare professionals should be aware of the risks and fully evaluate all medications and supplements which patients use in order to prevent polypharmacy (14).

A pharmacist is able, within his own domain of expertise, to identify the first signs of various diseases and to refer a patient for further medical examinations. He can detect drug-related issues, thus minimizing the risks, and he can also maximize the drug effect by supporting drug compliance, repeating instructions for use of the drug and recommending lifestyle changes; he can also help detect and minimise the impact of various risk factors (18). All these activities, including the alliance of doctor-patient-pharmacist, can reduce the incidence of complications which are usually costly and can reduce the quality of patient's life (19). Padiyara et al. showed that pharmacists can assist physicians and other clinicians in helping patients to implement preventive measures in diabetes, which may ultimately decrease the rate of complications, reduce costs, and increase quality of life (20). Diabetes requires continuous medical care and persistent patient education and support, so that acute complications could be prevented, reducing the risk of late complications, adverse reactions and adverse drug interactions $(21,22)$. The role of healthcare professionals can therefore be very important in the management and therapy of type 2DM.

\section{Conclusion}

A multidisciplinary approach of healthcare professionals is recommended in the pharmacotherapy of chronic diseases. This will require a change in the focus of professional roles of doctors and pharmacist who have common goals, including the positive intent and mutual respect for each other. Pharmacists should be further considered as an integral component in the healthcare 
system for type 2 DM care, especially in terms of helping patients to reduce non-adherence and hence to improve health outcomes in patients who use herbal dietary supplements together with standard hypoglycemic medication. It is essential that doctors and pharmacists recognize the safety and efficacy issues prior to recommending herbal dietary supplements for diabetes care, because of limited data at present regarding the use of dietary supplements for diabetes care.

\section{Acknowledgements}

The study was supported by the Ministry of Science and Technological Development of the Republic of Serbia (Project no. 46013 and 43012).

\section{References}

1. Salas A, Acosta D, Ferri CP, Guerra M, Huang $Y$, Jacob KS, et al. The Prevalence, Correlates, Detection and Control of Diabetes among Older People in Low and Middle Income Countries. A 10/66 Dementia Research Group Population-Based Survey. PLoS One 2016; 11(2): e0149616. [CrossRef] [PubMed]

2. van Dieren S, Beulens JW, van der Schouw YT, Grobbee DE, Neal B. The global burden of diabetes and its complications: an emerging pandemic. Eur J Cardiovasc Prev Rehabil 2010; 17 (1): S3-8. [PubMed]

3. Norris SL, Lau J, Smith SJ. Self-management educations for adults with type 2 diabetes: a metaanalysis of the effect on glycaemic control. Diabetes Care 2002; 25(7): 1159-71. [CrossRef][PubMed]

4. Tiwari P, Mishra BN, Sangwan NS. Phytochemical and pharmacological properties of Gymnema sylvestre: an important medicinal plant. Biomed Res Int 2014; 2014: 830285.

5. Martins AP, Miranda Ada C, Mendes Z, Soares MA, Ferreira $P$, Nogueira A. Self-medication in a Portuguese urban population: a prevalence study. Pharmacoepidemiol Drug Saf 2002; 11(5): 409-14. [CrossRef][PubMed]

6. Smith JD, Clinard VB. Natural products for the management of type 2 diabetes mellitus and comorbid conditions. J Am Pharm Assoc 2014; 54 (5): e304-18. [CrossRef][PubMed]

7. Bang S, Sontakke S, Thawani V. Pre and postinterventional pattern of self medication in three common illnesses in staff of a tertiary hospital. Indian J Pharmacol 2011; 43(3): 275-277. [CrossRef] [PubMed]

8. Awad A, Al-Rabiy S, Abahussain E. Self-medication practices among diabetic patients in Kuwait. Med Princ Pract 2008; 17(4): 315-20. [CrossRef] [PubMed]

9. Balamurugan E, Ganesh K. Prevalence and Pattern of Self Medication use in coastal regions of South India. BJMP 2011; 4: 428.

10. Ayele K, Tesfa B, Abebe L, Tilahun T, Girma E. Self care behavior among patients with diabetes in Harari, Eastern Ethiopia: the health belief model perspective. PLoS One 2012; 7 (4): e35515. [CrossRef][PubMed]

11. Kaufman DW, Kelly JP, Rosenberg L, Anderson TE, Mitchell AA. Recent patterns of medication use in the ambulatory adult population of the United States: the Slone survey. JAMA 2002; 287(3): 33744. [CrossRef][PubMed]
12. Al-Asadi J, Salih N. Herbal remedies use among diabetic patients in Nassyria, Iraq. Middle East Journal Of Family Medicine 2012; 10: 40-6. [PubMed]

13. Yeh GY, Eisenberg DM, Kaptchuk TJ, Phillips RS. Systematic review of herbs and dietary supplements for glycemic control in diabetes. Diabetes Care 2003; 26(4): 1277-94. [CrossRef] [PubMed]

14. Moen J, Antonov K, Larsson CA, Lindblad U, Nilsson $J \mathrm{~L}$, Rastam $\mathrm{L}$, et al. Factors associated with multiple medication use in different age groups. Ann Pharmacother 2009; 43(12): 1978-85. [CrossRef] [PubMed]

15. Heller T, Müller N, Kloos C, Wolf G, Müller UA. Self medication and use of dietary supplements in adult patients with endocrine and metabolic disorders. Exp Clin Endocrinol Diabetes 2012; 120 (9): 540-6. [CrossRef][PubMed]

16. Fakeye TO, Adisa R, Showande SJ. Attitude and opinion of Nigerian community pharmacists to self medication practices. Afr J Pharm Pharmaco 2012; 6: 1147-52. [CrossRef]

17. Silva IM, Catrib AM, de Matos VC, Gondim AP. Selfmedication in adolescence: a challenge to health education. Cien Saude Colet 2011; 16 (1): 165160. [CrossRef][PubMed]

18. Kirwin JL, Cunningham RJ, Sequist TD. Pharmacist recommendations to improve the quality of diabetes care: a randomized controlled trial. J Manag Care Pharm 2010; 16(2): 104-13. [CrossRef][PubMed]

19. Mehuys E, Van Bortel L, De Bolle L, Van Tongelen I, Annemans L, Remon JP, et al. Effectiveness of a community pharmacist intervention in diabetes care: a randomized controlled trial. J Clin Pharm Ther 2011; 36 (5): 602-13. [CrossRef][PubMed]

20. Padiyara RS, D'Souza JJ, Rihani RS. Clinical pharmacist intervention and the proportion of diabetes patients attaining prevention objectives in a multispecialty medical group. J Manag Care Pharm 2011; 17(6): 456-62. [CrossRef][PubMed]

21. Lee PY, Lee YK, Khoo EM, Ng CJ. How do health care professionals assess patients when initiating insulin therapy? A qualitative study. Prim Care Diabetes 2014; 8(1):49-55. [CrossRef] [PubMed]

22. Raaijmakers LG, Martens MK, Bagchus C, de Vries NK, Kremers SP. Perceptions of Dutch health care professionals regarding the Care Standard for diabetes. BMC Res Notes 2013; 6: 417. [CrossRef] [PubMed] 


\title{
UPOTREBA BILJNIH DIJETETSKIH SUPLEMENATA KOD BOLESNIKA SA DIJABETESOM: ULOGA ZDRAVSTVENIH PROFESIONALACA
}

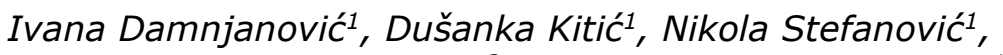 \\ Snežana Zlatković-Guberinić2 , Aleksandra Catić-Đorđević ${ }^{1}$, \\ Radmila Veličković-Radovanović1,3
}

\author{
${ }^{1}$ Univerzitet u Nišu, Medicinski fakultet, Katedra za farmaciju, Srbija \\ 2Zdravstvena ustanova "Apoteka Remedia", Niš, Srbija \\ ${ }^{3}$ Klinika za nefrologiju, Klinički centar Niš, Niš, Srbija \\ Kontakt: Ivana Damnjanović \\ Univerzitet u Nišu, Medicinski fakultet, Katedra za farmaciju, \\ Bulevar dr Zorana Đinđica 81, 18000 Niš, Serbia \\ E-mail: ivanad.ph@gmail.com
}

Danas je upoteba biljnih dijetetskih suplemenata veoma popularna, uz mišljenje da je u kombinaciji sa konvencionalnim antidijabeticima apsolutno bezbedna i opravdana. Cilj ovog istraživanja bio je da se ispita potencijalna uloga zdravstvenih profesionalaca prilikom izbora biljnih dijetetskih suplemenata sa hipoglikemiskim efektom u grupi obolelih od dijabetes, mellitusa tip 2.

Istraživanje u obliku analitičke studije preseka sprovedeno je u šest apoteka na teritoriji Niša tokom oktobra 2013. godine. Kriterijum za uključivanje ispitanika u istraživanje bili su bolesnici oboleli od dijabetesa melitusa tip 2 koji, pored propisane terapije, koriste i biljne suplemente.

Ispitanice ženskog pola učestalije su koristile biljne suplemente u odnosu na ispitanike muškog pola $(P<0,001)$. Zabeležena je statistički značajna razlika između starosnih grupa ispitanika u odnosu na uticaj zdravstvenih profesionalaca i medija na donošenje odluke o upotrebi biljnih dijetetskih suplemenata.

Neophodan je multidisciplinarni pristup zdravstvenih radnika u okviru farmakoterapije hroničnih bolesti. Vrlo je važno da lekari i farmaceuti prepoznaju bezbednost i efikasnost prilikom predlaganja biljnih dijetetskih suplemenata sa hipoglikemijskim efektom zbog malog broja dostupnih podataka o upotrebi ovih suplemenata u terapiji dijabetesa.

Acta Medica Medianae 2017;56(4):25-30.

Ključne reči: biljni dijetetski suplemenati, bolesnici oboleli od dijabetesa, zdravstveni profesionalci 